\title{
PENGARUH KEPEMILIKAN INSTITUSIONAL DAN DEWAN KOMISARIS INDEPENDEN TERHADAP TAX AVOIDANCE PADA PERUSAHAAN LQ-45 YANG TERDAFTAR DI BEI PERIODE 2015-2017
}

\author{
NensiYuniarti $\mathrm{Zs}^{1}$,Elvis Nopriyanti Sherly ${ }^{2}$, Dewi Nopita Sari ${ }^{3}$ \\ ${ }^{123}$ Fakultas Ekonomi dan Bisnis Universitas Muhammadiyah Bengkulu \\ Email: nensiyuniarti@umb.ac.id, elvisnopriyantisherly@gmail.com
}

\begin{abstract}
ABSTRAK
Penelitian ini bertujuan untuk mengetahui (1) pengaruh Kepemilikan Institusional terhadap penghindaran pajak (tax avoidance) dan (2) pengaruh Dewan Komisaris Independen terhadap penghindaran pajak (tax avoidance) pada perusahaan LQ-45 yang terdaftar di Bursa Efek Indonesia pada tahun 2015-2017. Penelitian ini merupakan penelitian kuantitatif. Sampel dalam penelitian terdiri dari 29 perusahaan dengan metode purposive sampling. Data yang digunakan merupakan data sekunder yang diambil dari website www.idx.co.id dengan analisis yang digunakan merupakan analisis regresi linear berganda. Berdasarkan hasil dari analisis regresi berganda dengan tingkat signifikansi 5\% maka dapat disimpulkan kepemilikan institusional dan dewan komisaris independen berpengaruh signifikan terhadap penghindaran pajak (tax avoidance). Berdasarkan hasil penelitian pada penelitian selanjutnya juga disarankan untuk memasukkan variabel lain yang mungkin mempengaruhi penghindaran pajak seperti kualitas audit, komite audit, kompensasi manajemen dan kepemilikan manajerial.
\end{abstract}

Kata Kunci: Kepemilikan institusional, dewan komisaris independen, penghindaran pajak (tax avoidance).

\section{ABSTRACT}

This study aims to examine (1) Institutional ownership Against Tax Avoidance and (2) Independent Board of Commissioners Against Tax Avoidance in LQ-45 companies registered in Indonesia Stock Exchange (IDX). This research is quantitative research. The population in this study were all LQ-45 companies listed on the Stock Exchange in 2015-2017. While the sample of this study was determined by purposive sampling method to obtain 29 sample companies. The type of data used is secondary data obtained from www.idx.co.id and sample company websites. The analytical method used is multiple linear regression analysis. Based on the results of multiple linear regression analysis with a significance level of $5 \%$, the results of the study concluded: institutional ownership and independent board of commissioners proved to have a significant effect on tax avoidance. The results of this study, it is suggested to add other variables that are thought to influence tax avoidance such as: audit quality, audit committee, management compensation, and managerial ownership.

Keywords: Institutional Ownership, Independent Board of Commissioners, and Tax Avoidance 


\section{PENDAHULUAN}

Undang-Undang Republik Indonesia Nomor 28 Tahun 2007 Pasal 1 ayat 1 menyatakan bahwa "Pajak adalah kontribusi wajib kepada negara yang terhutang oleh orang pribadi atau badan yang bersifat memaksa berdasarkan Undang-Undang, dengan tidak mendapatkan imbalan secara langsung dan digunakan untuk keperluan bagi sebesar-besarnya kemakmuran rakyat". Pajak merupakan beban bagi perusahaan yang dapat mengurangi laba bersih suatu perusahaan, sehingga banyak perusahaan yang berupaya untuk memperkecil pajak, untuk memperkecil pajak yang harus dibayarkan maka perusahaan melakukan manajemen pajak. Salah satu manajemen pajak yang dapat dilakukan oleh perusahaan yaitu dengan penghindaran pajak (tax avoidance). Menurut Fenny Winata (2014) Penghindaran pajak (tax avoidance) merupakan upaya penghindaran pajak yang memiliki dampak terhadap kewajiban pajak yang dilakukan dengan cara masih tetap dalam ketentuan perpajakan tidak melanggar ketentuan perpajakan yang telah ditetapkan, penghindaran pajak (tax avoidance) tidak melanggar hukum dan di perbolehkan oleh undang-undang perpajakan, namun dengan di berlakukannya penghindaran pajak (tax aviodance) ini menimbulkan kurangnya pemasukan yang diterima oleh negara.

Terkait dengan penghindaran pajak (tax avoidance) di Indonesia terdapat beberapa fenomena perusahaan yang melakukan tindakan penghindaran pajak (tax avoidance) salah satunya yaitu kasus PT Rajawali Nusantara Indonesia (RNI). Sebuah perusahaan yang bergerak di bidang jasa kesehatan terafiliasi perusahaan di Singapura, yakni PT RNI, yang kini tengah menjalani proses pemeriksaan oleh Kantor Wilayah Direktorat Jenderal Pajak (DJP) Jakarta Khusus. Perusahaan tersebut diduga melakukan upaya-upaya penghindaran pajak (tax avoidance), padahal memiliki aktivitas cukup banyak di Indonesia yakni di Jakarta, Solo, Semarang, dan Surabaya. dalam kasus ini PT RNI sudah terdaftar sebagai perseroan terbatas, namun dari segi permodalan, perusahaan tersebut menggantungkan hidup dari utang afiliasi. Artinya, pemilik di Singapura memberikan pinjaman kepada RNI di Indonesia. Sedangkan modal yang digunakan oleh PT RNI tersebut masih bergantung pada utang afiliasi. Lantaran modal yang digunakan oleh PT RNI berasal dari utang maka perusahaan tersebut akan terhindarkan dari kewajibannya. Apalagi laporan keuangannya mengalami kerugian maka praktis tidak melakukan kewajiban perpajakan. Laporan keuangan PT RNI tahun 2014, menunjukkan utang sebesar RP 20,4 M. Sedangkan omzet yang didapat oleh PT RNI tersebut hanya sebesar Rp 2,178 M dan pada tahun yang sama masih terdapat kerugian ditahan senilai 26,12M. Strategi yang dilakukan oleh PT RNI yaitu memanfaatkan Peraturan Pemerintah 46/2013 tentang Pajak Penghasilan khusus UMKM, dengan tarif PPh final 1 persen. Selain itu, dua pemegang saham PT RNI berkewaganegaraan Indonesia tidak melaporkan SPT pajak secara benar sejak 2007-2015 dan pemegang saham yang berasal dari Singapura tidak melaporkan pajak penghasilannya padahal memiliki usaha di Indonesia.

Penghindaran pajak (tax avoidance) salah satunya dapat diminimalisir melalui kepemilikan institusional dan dewan komisaris independen.Para investor cenderung menghindari perusahaanperusahaan yang memiliki tata kelola perusahaan yang buruk dan memperhatikan perusahaan yang memiliki tata kelola yang baik akan berdampak pada kesejahteraan bagi pihak-pihak yang berkepentingan (stakeholders) dan nilai perusahaan.Nilai Perusahaan merupakan suatu indikator keberhasilan kinerja suatu perusahaan dalam mencapai penghargaan dari lingkungan bisnis, bertujuan menciptakan kekayaan bagi perusahaan atau memaksimumkan laba, agar tujuan perusahaan tercapai memerlukan pengendalian manajemen, salah satu cara melakukan penghindaran pajak.(Soerzawa, Yusmaniarti, \& Suhendra, 2018). Penelitian yang dilakukan oleh Sartori, Nicola (2010) menjelaskan bahwa apabila suatu perusahaan memiliki suatu mekanisme goodcorporate governance yang terstruktur dengan baik maka akan berbanding lurus dengan kepatuhan dalam memenuhi kewajiban perpajakannya.

Menurut Tendi Haruman (2008) Good Corporate governance merupakan tata kelola perusahaan yang menjelaskan hubungan antara berbagai partisipan dalam perusahaan yang 
menentukan arah kinerja perusahaan. Sedangkan penelitian yang dilakukan oleh Fenny Winata (2014) good corporate governance memiliki andil dalam pengambilan keputusan, termasuk dalam hal mengambil keputusan untuk memenuhi kewajiban pajaknya. Good Corporate Governance yang diterapkan dengan baik seharusnya sejalan dengan definisi pajak yaitu pajak adalah sebagai kewajiban. Penelitian ini dilakukan pada perusahaan LQ-45 yang terdaftar di BEI pada tahun 20152017. Penelitian ini memfokuskan pada variabel independen yang memiliki pengaruh terhadap tax avoidance yaitu good corporate governance yang diproksikan kepemilikan institusional dan dewan komisaris independen. Berdasarkan hasil penelitian yang telah dilakukan terdahulu dan hasilnya menunjukkan belum konsistennya hasil dari penelitian terdahulu, maka peneliti tertarik untuk menguji kembali penelitian mengenai tax avoidance ini dengan pengambilan sampel perusahaan LQ-45 dari tahun 2015-2017 dengan judul penelitian"Pengaruh Kepemilikan Institusional dan Dewan Komisaris Independen terhadap Tax Avoidance".

\section{TINJAUAN LITERATUR}

\section{Teori Agency}

Jansen dan Mecking (1976) mengemukakan definisi agency theory adalah sebagai berikut: "Hubungan keagenan muncul pada saat satu atau lebih pemilik perusahaan mempekerjakan manajer perusahaan yang bertujuan untuk memberikan jasa dan memberikan kekuasaan kepada agen tersebut untuk membuat suatu keputusan atas nama principal tersebut". Dalam kegiatan usahanya pemilik perusahaan memberikan wewenang atau tanggung jawab kepada pihak manajemen perusahaan dalam rangka pengambilan keputusan diharapkan dapat memaksimalkan sumber daya yang dimiliki oleh perusahaan dengan tujuan untuk mensejahterakan pemilik perusahaan baik dalam rentang waktu jangka pendek maupun jangka panjang. Manajer perusahaan merupakan pengelola dari suatu perusahaan yang lebih mengetahui tentang informasi internal bahkan prospek perusahaan tersebut pada masa yang akan datang jika dibandingkan dengan pemilik perusahaan.

Menurut Warsono dkk (2009) dalam Nuralifmida Ayu Annisa (2011) Terdapat cara-cara langsung yang digunakan pemegang saham untuk memonitor manajemen perusahaan sehingga membantu memecahkan konflik keagenan. Pertama, pemegang saham mempunyai hak untuk mempengaruhi cara perusahaan dijalankan melalui voting dalam rapat umum pemegang saham , hak voting pemegang saham merupakan bagian penting dari asset keuangan mereka. Kedua, pemegang saham melakukan resolusi dimana suatu kelompok pemegang saham secara kolektif melakukan lobby terhadap manajer (mewakili perusahaan) berkenaan dengan isu-isu yang tidak memuaskan mereka. Pemegang saham juga mempunyai opsi divestasi (menjual saham mereka), divestasi mereprestasikan suatu kegagalan dari perusahaan untuk mempertahankan investor, dimana divestasi diakibatkan oleh ketidakpuasan pemegang saham atas aktivitas manajer. Implikasi teori keagenan terhadap penelitian ini dapat menjelaskan bahwa manajemen tidak bisa terlepas dari tindakan penghindaran pajak. Manajemen melakukan tindakan penghindaran pajak karena ingin memaksimalkan laba perusahaan untuk mengimbangi keinginan dari pemilik perusahaan yaitu menghasilkan laba yang sebesar-besarnya. Selain itu agar kinerja manajemen dapat dinilai baik dan meningkat dari tahun ke tahun.

\section{Theory of Planned Behavior}

Tindak penghindaran pajak yang dilakukan oleh perusahaan tidak bisa lepas dari adanya Theory of Planned Behavior, teori ini menjelaskan tentang kecenderungan penghindaran pajak oleh perusahaan yang sebelumnya telah direncanakan secara sengaja. Ajzen, I (1991) menjelaskan bahwa perilaku individu melakukan tindakan tidak patuh terhadap ketentuan perpajakan karena dipengaruhi oleh niat untuk berperilaku tidak patuh. Sebelum individu melakukan hal tersebut, individu akan memiliki keyakinan mengenai hasil yang akan diperoleh atas perilaku yang telah 
diperbuatnya. Kemudian mereka akan memutuskan bahwa akan melakukannya atau tidak melakukannya. Hal tersebut berkaitan dengan kesadaran wajib pajak, karena keyakinan mengenai pentingnya membayar pajak untuk membantu menyelenggarakan pembangunan Negara.

Menurut Tryana A.M. Tiraada (2013) munculnya niat untuk berperilaku ditentukan oleh tiga faktor, yaitu: (1). Behavioral Beliefs. Behavioral beliefs merupakan keyakinan individu akan hasil dari suatu perilaku dan evaluasi atas hasil dari tindakan yang dilakukannya tersebut; (2) Normative Beliefs. Normative beliefs yaitu keyakinan tentang harapan normatif orang lain dan motivasi untuk memenuhi harapan tersebut. Atau normative belief dapat juga diartikan sebagai kepercayaankepercayaan atau motivasi mengenai suatu harapan-harapan yang diinginkan, dan harapan tersebut muncul karena pengaruh dari orang lain; (3) Control Beliefs. Control beliefs merupakan keyakinan atau kepercayaan tentang adanya keberadaan hal-hal yang dapat mendukung atau menghambat perilaku yang akan ditampilkan. Selain itu suatu persepsi seseorang akan muncul, dan persepsi tersebut juga berhubungan tentang seberapa kuat hal-hal yang mendukung dan menghambat perilakunya tersebut.

\section{Kerangka Pemikiran}

Kerangka teoritis membantu menjelaskan hubungan antar variabel independen terhadap variabel dependen, yaitu kepemilikan institusional, dan dewan komisaris independen terhadap tax avoidance. Berdasar pada telaah literatur yang tertulis di atas, maka kerangka pemikiran yang di kembangkan dalam penelitian ini secara ringkas digambarkan sebagai berikut:

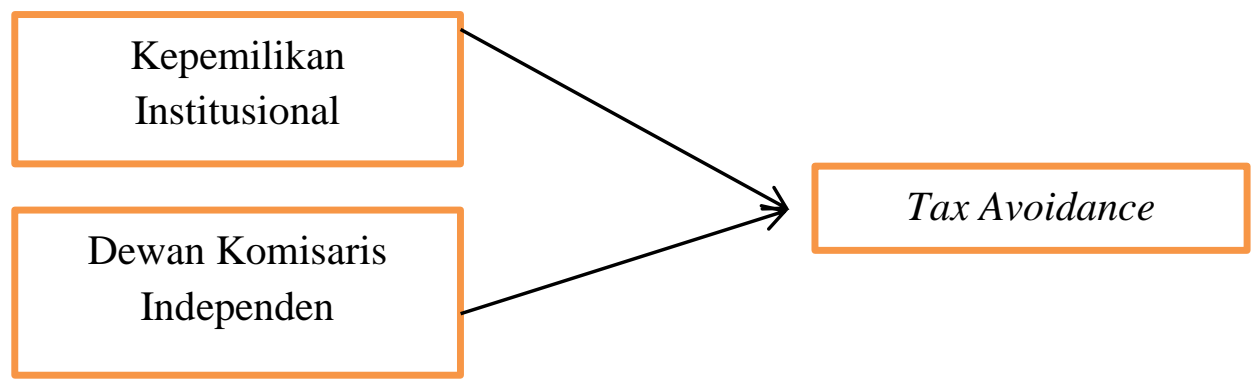

\section{RUMUSAN HIPOTESIS}

\section{Pengaruh Kepemilikan Institusional Terhadap Penghindaran Pajak (Tax Avoidance)}

Jensen dan Meckling (1976) menyatakan bahwa kepemilikan manajerial dan kepemilikan institusional adalah dua mekanisme corporate governance yang dapat mengendalikan masalah keagenan. Ngadiman dan Puspitasari (2014) menyatakan bahwa Kepemilikan institusional merupakan kepemilikan saham oleh pemerintah, institusi keuangan, institusi berbadan hukum, institusi luar negeri, dan dana perwalian serta institusi lainnya. Institusi-institusi tersebut memiliki wewenang untuk melakukan pengawasan atas kinerja manajemen. Menurut Hashemi dan Zulaikha (2013) dengan adanya kepemilikan institusional di suatu perusahaan maka kepatuhan dan kinerja manajemen akan meningkat. Semakin besar kepemilikan institusi keuangan maka akan semakin besar kekuatan suara dan dorongan dari institusi keuangan tersebut untuk mengawasi manajemen dan akibatnya akan memberikan dorongan yang lebih besar untuk mematuhi peraturan perpajakan. Investor institusional memilki andil didalam keputusan maka secara otomatis akan mendorong manajemen untuk mematuhi peraturan yang dibuat pemerintah sehingga perusahaan patuh terhadap 
pajak. Dengan begitu, perusahaan akan menghindari perilaku penghindaran pajak (tax avoidance) yang menyimpang dari ketetapan pajak yang sesuai di negeri ini.

Berdasarkan penelitian Fenny Winata (2014) menunjukkan hasil penelitian bahwa kepemilikan institusional berpengaruh signifikan terhadap penghindaran pajak. Penelitian ini sejalan dengan hasil penelitian yang dilakukan oleh Hotman Tohir Pohan (2008) dan Nuralifmida Ayu Annisa (2011). Sehingga hipotesis pertama yang akan diuji sebagai berikut:

H1: Kepemilikan institusional berpengaruh signifikan terhadap penghindaran pajak ( $\operatorname{tax}$ avoidance).

\section{Pengaruh Dewan Komisaris Independen Terhadap Penghindaran Pajak (Tax Avoidance)}

Menurut Elsiana Ruddian (2017) Komisaris independen sebagai pihak yang tidak mempunyai hubungan bisnis dan kekeluargaan dengan pemegang saham pengendali, anggota direksi dan dewan komisaris lain harus secara proaktif mengupayakan agar dewan komisaris melakukan pengawasan dan memberikan nasehat kepada direksi untuk memastikan bahwa prinsip-prinsip dan praktik Good Corporate Governance diterapkan dengan baik, mematuhi hukum dan perundangan yang berlaku serta menerapkan nilai-nilai yang ditetapkan perusahaan dalam menjalankan operasinya. Salah satu syarat pencatatan saham bagi calon perusahaan tercatat adalah memiliki komisaris independen sekurang- kurangnya 30\% dari jajaran anggota Dewan Komisaris, apabila jumlah komisaris independen pada dewan komisaris semakin banyak, maka akan semakin baik karena komisaris independen dapat memenuhi peran mereka didalam fungsi monitoring terhadap tindakan-tindakan para direktur, maka aktivitas tax avoidance akan semakin rendah.

Berdasarkan pandangan Nurshamim Sabli (2011), komisaris independen melakukan pengawasan yang sangat baik yaitu dengan mengarahkan perusahaan berdasarkan aturan yang telah ditetapkan. Menurut Maria Andriyani (2008) komisaris independen dapat melaksanakan fungsi monitoring untuk mendukung pengelolaan perusahaan yang baik dan menjadikan laporan keuangan lebih obyektif. Komite audit bertugas melakukan kontrol dalam proses penyusunan laporan keuangan perusahaan untuk menghindari kecurangan pihak manajemen. Berjalannya fungsi komite audit secara efektif memungkinkan pengendalian pada perusahaan dan laporan keuangan yang lebih baik serta mendukung good corporate governance. Penelitian Fenny Winata (2014) dapat membuktikan bahwa proporsi dewan komisaris independen berpengaruh signifikan terhadap tax avoidance. Sehingga hipotesis kedua dapat dirumuskan sebagai berikut :

H2: Dewan komisaris independen berpengaruh signifikan terhadap penghindaran pajak (tax avoidance).

\section{METODE}

\section{Defenisi Operasional dan Pengukuran Variabel}

Dalam penelitian ini terdapat satu variabel dependen yaitu Tax Avoidance, sedangkan variabel independennya yakni kepemilikan institusional dan dewan komisaris independen.

\section{Cash ETR (cash effective tax rate)}

Menurut Chen et al (2010) menghitung penghindaran pajak (tax avoidance) dengan proksi cash ETR (cash effective tax rate) perusahaan yaitu kas yang dikeluarkan untuk biaya pajak dibagi dengan laba sebelum pajak. Semakin besar cash ETR ini mengindikasikan semakin rendah tingkat penghindaran pajak perusahaan.

$$
\text { cash } \mathrm{ETR}=\frac{\text { current tax paid }}{\text { pre }- \text { Tax Income }}
$$




\section{Kepemilikan Institusional}

Menurut Elsiana Ruddian (2017) kepemilikan institusional sebagai pengawas yang berasal dari luar perusahaan memegang peranan penting dalam memonitoring manajemen. Indikator yang digunakan dalam mengukur suatu kepemilikan institusional adalah dengan persentase jumlah saham yang dimiliki oleh pihak institusi dari seluruh jumlah modal saham yang beredar. Kepemilikan institusional dapat diukur dengan rumus:

$$
\text { kepemilikan institusional }=\frac{\text { kepemilikan saham institusional }}{\text { total saham beredar }}
$$

\section{Dewan komisaris independen}

Menurut Elsiana Ruddian (2017) Komisaris independen adalah anggota dewan komisaris yang berasal dari luar perusahaan. Variabel tersebut diukur berdasarkan presentase jumlah dewan komisaris terhadap total komisaris yang ada dalam jajaran dewan komisaris perusahaan. Independensi Dewan Komisaris diukur dengan rumus sebagai berikut :

$$
\text { Proporsi dewan komisaris }=\frac{\text { jumlah } \text { komisaris independen }}{\text { total komisaris }}
$$

\section{Uji Asumsi Klasik}

\section{Uji Normalitas}

Uji normalitas dipakai dalam menentukan data yang sudah dikumpulkan tersebut berdistribusi normal atau tidak (Nazaruddin dan Agus, 2015). Model regresi dapat dikatakan baik apabila model regresi yang memiliki nilai residual yang mengikuti berdistribusi normal. Uji normalitas dideteksi dengan analisis grafik histogram, normal probability plot, dan analisis statistik non-parametrik Kolmogorov-Smirnov Z (1-Sample K-S) yang menunjukkan bahwa variabel akan terdistribusi secara normal maupun tidak normal. Dapat dikatakan normal jika hasil analisis nilai sig $>0.05$ maka model regresi dikatakan normal.

\section{Uji Autokorelasi}

Uji autokorelasi digunakan untuk mengetahui apakah terjadi korelasi antara residual (anggota) pada serangkaian observasi tertentu dalam suatu periode tertentu. Penelitian ini menggunakan alat uji autokorelasi yaitu uji Durbin-Watson (Uji DW). Model yang bebas autokorelasi adalah model yang nilai dW-nya lebih besar dari dU dan nilai dW-nya lebih kecil dari 4-dU dengan kata lain dU $<\mathrm{dW}<4-\mathrm{dU}$ (Ghozali, 2013). Pengambilan keputusan ada atau tidaknya autokorelasi pada suatu model diperlihatkan pada Tabel berikut:

Kriteria Autokorelasi Durbin-Watson

\begin{tabular}{|l|l|l|}
\hline \multicolumn{1}{|c|}{ Hipotesis Nol } & \multicolumn{1}{c|}{ Keputusan } & \multicolumn{1}{c|}{ Jika } \\
\hline Tidak ada autokorelasi positif & Tolak & $0<\mathrm{d}<\mathrm{dl}$ \\
\hline Tidak ada autokorelasi positif & Tidak ada keputusan & $\mathrm{dl} \leq \mathrm{d} \leq \mathrm{du}$ \\
\hline Tidak ada autokorelasi negatif & Tolak & $4-\mathrm{dl} \leq \mathrm{d} \leq 4$ \\
\hline Tidak ada autokorelasi negatif & Tidak ada keputusan & $4-\mathrm{du} \leq \mathrm{d} \leq 4-\mathrm{dl}$ \\
\hline $\begin{array}{l}\text { Tidak ada autokorelasi positif atau } \\
\text { negatif }\end{array}$ & Tidak ditolak & $\mathrm{du}<\mathrm{d}<4-\mathrm{du}$ \\
\hline
\end{tabular}

Sumber: (Ghozali, 2013) 


\section{Uji Multikolinearitas}

Uji multikolinearitas bertujuan untuk menguji apakah model regresi mempunyai korelasi antara variabel bebas (independen). Model regresi yang baik seharusnya antara variabel bebas tidak terjadi korelasi. Untuk mengetahui data tersebut terdapat ataupun tidak terdapat multikolinearitas di dalam model regresi menurut Ghozali (2013), dapat dilakukan dengan melihat nilai VIF (Variance Inflation Factor) < 10 dan tolerance >0,10.

\section{Uji Heteroskedastisitas}

Uji heteroskedastisitas digunakan untuk menguji apakah dalam model regresi terjadi ketidaksamaan varian untuk semuaa pengamatan pada model regresi. Jika variance dari residual satu pengamatan ke pengamatan yang lain tetap, maka disebut heteroskedastisitas. Model regresi yang baik adalah yang tidak terjadi heteroskedastisitas. Untuk mendeteksi ada atau tidaknya heteroskedastisitas digunakan uji glejser. Uji glejser di uji dengan cara meregresi variabel dependen dengan nilai absolute dari residual (Abs_Res). Jika hasil pengujian diperoleh nilai sig > 0,05 maka tidak terjadi heteroskesdastisitas.

\section{Teknik Analisis Data}

Teknik analisis data dalam penelitian ini menggunakan teknik analisis regresi berganda. Analisis regresi berganda adalah alat analisis peramalan nilai pengaruh dari dua variabel bebas atau lebih terhadap variabel terikat untuk membuktikan ada atau tidaknya hubungan fungsi atau kausal antara dua variabel bebas atau lebih dengan satu variabel terikat (Ghozali, 2013). Penelitian ini dihitung dengan menggunakan model regresi linear berganda sebagai berikut:

\section{$\mathrm{TA}=\alpha+\beta 1 \mathrm{KI}+\beta 2 \mathrm{DKI}+\varepsilon$}

\section{HASIL DAN PEMBAHASAN}

\section{Populasi dan Sampel Penelitian}

Populasi dalam penelitian ini adalah seluruh perusahaan LQ-45 yang terdaftar diBursa Efek Indonesia (BEI) dari tahun 2015 sampai tahun 2017. Sampel yang digunakan dalam penelitian ini yaitu perusahaan manufaktur yang terdaftardi BEI dengan periode pengamatan ini dari tahun 20152017 yang memenuhi kriteria.Teknik pengambilan sampel dalam penelitian ini menggunakan metode purposive sampling. Berdasarkan kriteria yang telah ditetapkan maka jumlah sampel dalam penelitian ini berjumlah 29 perusahaan dengan jumlah observasi sebanyak 87 observasi.

\section{Hasil Pengujian Asumsi Klasik}

\section{Uji Normalitas Data}

Hasil Pengujian Normalitas

One-Sample Kolmogorov-Smirnov Test

\begin{tabular}{|ll|r|}
\hline & & \multicolumn{2}{|c|}{ Unstandardized Residual } \\
\hline $\mathrm{N}$ & 62 \\
Normal & Mean & .0000000 \\
Parameters & ${ }^{\mathrm{a}}$ & Std. Deviation \\
Most Extreme & Absolute & .04514506 \\
Differences & Positive & .075 \\
& Negative & .075 \\
Kolmogorov-Smirnov Z & -.066 \\
Asymp. Sig. (2-tailed) & .590 \\
\hline
\end{tabular}

a. Test distribution is Normal.

Sumber : Data Sekunder diolah, 2019 
Berdasarkan hasil pengujian one sampel kolmogrov smirnov (KS), terlihat bahwa semua variabel memiliki asymp. Sig (2-tailed) lebih besar dari 0,05 maka menunjukan semua variabel telah terdistribusi secara normal dengan nilai probabilitas $>0,05$ yang artinya data telah terdistribusi secara normal.

\section{Uji Autokorelasi}

Hasil Uji Autokorelasi

\begin{tabular}{|c|c|c|c|c|c|c|}
\hline \multicolumn{7}{|c|}{ Pengujian autokorelasi awal } \\
\hline Model & $\mathrm{K}$ & $\mathrm{dL}$ & $\mathrm{Du}$ & $\begin{array}{c}\text { Durbin } \\
\text { Watson }\end{array}$ & Kriteria & Keterangan \\
\hline Model & 4 & 1,5567 & 1,7485 & 1,327 & $\begin{array}{c}\mathrm{dU}<\mathrm{dW}<4- \\
\mathrm{dU}\end{array}$ & $\begin{array}{c}\text { Terkena } \\
\text { Autokorelasi }\end{array}$ \\
\hline
\end{tabular}

Sumber: Data Sekunder diolah, 2019

Berdasarkan tabel diatas hasil pengujian autokorelasi pada model 1 variabel bebas dan jumlah observasi sebanyak 87, diperoleh nilai dL sebesar 1,5567 dan nilai Durbin-Watson sebesar 1,327. Nilai Durbin-Watson yang lebih rendah dari pada nilai dU meunjukan bahwa model 1 terkena masalah autokorelasi. Untuk mengatasi masalah autokorelasi tersebut, dilakukan tindakan membentuk variabel baru pada seluruh model regresi dengan cara melakukan transform cochranceorcutt. Setelah dilakukan perbaikan maka dilakukan pengujian autokorelasi secara ulang dengan menggunakan model persamaan regresi yang baru. Hasil uji autokorelasi setelah perbaikan model dapat dilihat pada tabel berikut:

Hasil Uji Autokorelasi (setelah diperbaiki)

\begin{tabular}{|c|c|c|c|c|c|c|}
\hline \multicolumn{7}{|c|}{ Pengujian autokorelasi sebelum diperbaiki } \\
\hline Model & $\mathrm{K}$ & $\mathrm{dL}$ & $\mathrm{Du}$ & $\begin{array}{c}\text { Durbin } \\
\text { Watson }\end{array}$ & Kriteria & Keterangan \\
\hline Model & 4 & 1,4554 & 1,7288 & 1,940 & $\begin{array}{c}\mathrm{dU}<\mathrm{dW}<4- \\
\mathrm{dU}\end{array}$ & $\begin{array}{c}\text { Bebas } \\
\text { Autokorelasi }\end{array}$ \\
\hline
\end{tabular}

Sumber: Data Sekunder diolah, 2019

Pada tabel diatas dapat dilihat bahwa model persamaan telah bebas dari masalah autokorelasi karena pada model persamaan nilai dW lebih besar dari pada dU dan lebih rendah daripada 4-dU yaitu $\mathrm{dU}<\mathrm{dW}<4$-dU sehingga dapat disimpulkan bahwa data bebas autokorelasi.

\section{Uji Multikolinearitas}

Uji multikolinieritas dilakukan dengan tujuan untuk menguji apakah model regresi ditemukan adanya korelasi di antara variabel independen. Model dikatakan baik jika tidak terjadi korelasi di antara variabel indepeneden (Ghozali, 2013). Untuk melihat ada atau tidaknya masalah multikolinieritas dapat dilihat dari nilai Tolerance dan Variance Inflation Factor (VIF). Jika nilai tolerance $>0,1$ dan nilai $V I F<10$ maka tidak terjadi masalah multikolinieritas dan model regresi dapat dikatakan baik. Sedangkan jika nilai tolerance $<0,1$ dan nilai VIF $>10$ maka terjadi masalah multikolinieritas. Hasil uji multikolinieritas dapat dilihat pada tabel berikut ini: 
Hasil Uji Multikolinearitas

\begin{tabular}{|l|c|c|c|}
\hline \multirow{2}{*}{ Variabel } & \multicolumn{2}{|c|}{ Collinearity Statistics } & \multirow{2}{*}{ Keterangan } \\
\cline { 2 - 3 } & Tolerance & VIF & \\
\hline KI1 & 0.726 & 1.377 & Bebas dari multikolearitas \\
\hline DKI1 & 0.654 & 1.529 & Bebas dari multikolearitas \\
\hline
\end{tabular}

Sumber: Data Sekunder diolah, 2019

Berdasarkan tabel diatas dapat dilihat bahwa tidak terdapat model persamaan yang terkena masalah multikolinearitas. Variabel kepemilikan institusional (KI) pada hipotesis 1 merupakan varibel independen memiliki nilai tolerance 0.726 nilai tersebut lebih besar dari 0,1 , selanjutnya nilai VIF sebesar 1.377 nilai tersebut $<10$, jadi variabel KI terbebas dari masalah multikolinearitas. Variabel dewan komisaris independen (DKI) pada hipotesis 2 merupakan variabel independen memiliki nilai tolerance 0.654 nilai tersebut lebih besar dari 0,1 , selanjutnya nilai VIF sebesar 1.529 nilai tersebut $<10$, jadi variabel DKI terbebas dari masalah multikolinearitas.

\section{Uji Heteroskedastisitas}

Pengujian heteroskedastisitas bertujuan untuk menguji apakah dalam model regresi terjadi ketidaksamaan variance dari residual satu observasi keobservasi yang lain. Dalam penelitian ini untuk menguji heteroskedastisitas digunakan uji glejser yang dilakukan dengan meregresikan variabel-variabel bebas terhadap nilai absolut residualnya (Ghozali, 2013). Jika koefisien korelasi semua variabel terhadap residual $>0,05$ dapat disimpulkan bahwa model regresi tidak terjadi heteroskedastisitas. Hasil uji heteroskedastisitas pada tabel dibawah ini:

Hasil Uji Heteroskedastisitas

\begin{tabular}{|l|r|r|l|}
\hline \multicolumn{1}{|c|}{ Model } & \multicolumn{1}{c|}{ T } & Sig. & Keterangan \\
\hline 1 (Constant) & 3.530 & .001 & \\
KI1 & -1.007 & .318 & Bebas Heteroskedastisitas \\
DKI1 & -2.003 & .050 & Bebas Heteroskedastisitas \\
\hline
\end{tabular}

Sumber: Data Sekunder diolah, 2019

Berdasarkan tabel diatas terlihat bahwa nilai variabel KI memiliki nilai signifikansi sebesar $0.318>0,05$, maka model regresi untuk variabel KI1 bebas heteroskedastisitas. Variabel DKI1 memiliki nilai signifikansi 0,050 >0,05, maka model regresi untuk DKI bebas heteroskedastisitas. Jadi keseluruhan model pada penelitian ini bebas masalah heteroskedastisitas.

\section{Pengujian Hipotesis}

Penelitian ini bertujuan untuk menjelaskan pengaruh kepemilikan institusional dan dewan komisaris independen terhadap tax avoidance. Hipotesis penelitian ini terdiri dari dua hipotesis. Dalam pengujian setiap hipotesis akan dilakukan secara terpisah sebagai berikut:

\section{Pengaruh kepemilikan institusional terhadap tax avoidance}

Hipotesis pertama yang akan diuji dalam penelitian ini adalah kepemilikan institusional berpengaruh secara signifikan terhadap penghindaran pajak (tax avoidance). Uji t digunakan pada seluruh model regresi untuk menguji hipotesis dalam penelitian ini. Pengujian dilakukan dengan menggunakan significance level 5\%. Hasil uji hipotesisnya dapat dilihat pada tabel berikut: 


\section{Hasil Uji Parsial (Uji t) \\ Coefficients $^{\mathrm{a}}$}

\begin{tabular}{|c|c|c|c|c|c|c|}
\hline \multirow[b]{2}{*}{ Model } & \multicolumn{2}{|c|}{$\begin{array}{c}\text { Unstandardized } \\
\text { Coefficients } \\
\end{array}$} & \multirow{2}{*}{$\begin{array}{c}\text { Standardized } \\
\text { Coefficients } \\
\text { Beta }\end{array}$} & \multirow[b]{2}{*}{$\mathrm{T}$} & \multirow[b]{2}{*}{ Sig. } & \multirow{2}{*}{ Keterangar } \\
\hline & B & Std. Error & & & & \\
\hline 1) (Constant & .134 & .016 & & 8.503 & .000 & - \\
\hline KI1 & .099 & .041 & .299 & 2.428 & .018 & Diterima \\
\hline
\end{tabular}

a. Dependent Variable: TA1

Sumber: Data Sekunder dioleh, 2019

Berdasarkan tabel tersebut hasil pengujian hipotesis pertama menunjukan koefisien regresi kepemilikan institusional (KI1) bernilai sebesar 0,099 nilai t sebesar 2.428 dan nilai signifikansi sebesar 0,018 (tingkat signifikansi < 0,05). Hal ini menunjukan bahwa kepemilikan institusional berpengaruh secara signifikan terhadap penghindaran pajak (tax avoidance). Hasil penelitian ini menunjukkan hasil yang konsisten dengan hipotesis pertama yang dibangun yaitu untuk menguji apakah kepemilikan institusional berpengaruh secara signifikan terhadap penghindaran pajak (tax avoidance) sehingga hipotesis pertama diterima.

Hal ini tidak sejalan dengan penelitian yang dilakukan oleh Fenny Winata (2014). Kepemilikan institusional yang berpengaruh signifikan terhadap penghindaran pajak (tax avoidance) memiliki arti bahwa besar kecilnya kepemilikan institusional bisa membuat praktik penghindaran pajak (tax avoidance) yang dilakukan oleh perusahaan tersebut dapat dihindari. Menurut Hashemi dan Zulaikha (2013) dengan adanya kepemilikan institusional di suatu perusahaan maka kepatuhan dan kinerja manajemen akan meningkat. Semakin besar kepemilikan institusi keuangan maka akan semakin besar kekuatan suara dan dorongan dari institusi keuangan tersebut untuk mengawasi manajemen dan akibatnya akan memberikan dorongan yang lebih besar untuk mematuhi peraturan perpajakan. Investor institusional memilki andil didalam keputusan maka secara otomatis akan mendorong manajemen untuk mematuhi peraturan yang dibuat pemerintah sehingga perusahaan patuh terhadap pajak. Dengan begitu, perusahaan akan menghindari perilaku penghindaran pajak (tax avoidance) yang menyimpang dari ketetapan pajak yang sesuai di negeri ini. Sedangkan menurut Wien Ika Permanasari (2010) menyatakan bahwa kepemilikan institusional memiliki peranan yang sangat penting dalam meminimalisasi konflik keagenan yang terjadi antara manajer dan pemegang saham. Keberadaan investor institusional dianggap mampu menjadi mekanisme monitoring yang efektif dalam setiap keputusan yang diambil oleh manajer. Hal ini disebabkan investor institusional terlibat dalam pengambilan yang strategis sehingga tidak mudah percaya terhadap tindakan manipulasi laba.

Hasil penelitian ini sejalan dengan hasil penelitian sebelumnya,antara lain penelitian yang dilakukan oleh Ayu Rahmawati (2016) dalam penelitiannya menyatakan bahwa kepemilikan institusional memiliki berpengaruh signifikan terhadap penghindaran pajak (tax avoidance), dan berbanding terbalik dengan penelitian yang dilakukan oleh Fenny Winata (2014) yang menunjukkan bahwa kepemilikan institusional tidak memiliki pengaruh yang signifikan terhadap penghindaran pajak (tax avoidance).

Pengaruh Dewan komisaris independen terhadap tax avoidance

Hipotesis kedua yang akan diuji dalam penelitian ini adalah dewan komisaris independen berpengaruh secara signifikan terhadap penghindaran pajak (tax avoidance). Uji t digunakan pada seluruh model regresi untuk menguji hipotesis dalam penelitian ini. Pengujian dilakukan dengan menggunakan significance level 5\%. Hasil uji parsial (uji t) dapat dilihat pada tabel berikut: 


\section{Hasil Uji Parsial (Uji t)}

Coefficients $^{\mathrm{a}}$

\begin{tabular}{|l|r|r|c|c|c|l|}
\hline & \multicolumn{2}{|c|}{$\begin{array}{c}\text { Unstandardized } \\
\text { Coefficients }\end{array}$} & $\begin{array}{l}\text { Standardized } \\
\text { Coefficients }\end{array}$ & & & \\
\cline { 2 - 5 } Model & $\mathrm{B}$ & Std. Error & Beta & \multicolumn{1}{c|}{$\mathrm{T}$} & \multicolumn{1}{c|}{ Sig. } & $\begin{array}{l}\text { Keteranga } \\
\mathrm{n}\end{array}$ \\
\hline 1 (Constant) & .229 & .021 & & 10.946 & .000 & - \\
DKI1 & -.196 & .065 & -.360 & -2.993 & .004 & Diterima \\
\hline
\end{tabular}

a. Dependent Variable: TA1

Sumber : Data Sekunder diolah, 2019

Berdasarkan tabel diatas hasil pengujian hipotesis kedua menunjukan koefisien regresi dewan komisaris independen (DKI1) bernilai sebesar -0.196 nilai t sebesar -2.993 dan nilai signifikansi sebesar 0,004 (tingkat signifikansi < 0,05). Hal ini menunjukan bahwa dewan komisaris independen berpengaruh secara signifikan terhadap penghindaran pajak (tax avoidance). Hasil penelitian ini menunjukkan hasil yang konsisten dengan hipotesis kedua yang dibangun yaitu untuk menguji apakah dewan komisaris independen berpengaruh secara signifikan terhadap penghindaran pajak (tax avoidance) sehingga hipotesis kedua diterima.Penelitian ini sejalan dengan penelitian yang dilakukan oleh Ayu Rahmawati (2016).

Penelitian ini menunjukkan bahwa semakin besar persentase variabel dewan komisaris independen dapat digunakan untuk melakukan pengawasan yang efektif dan pengendalian dalam sebuah perusahaan oleh direksi dan manajemen, sehingga keberadaan mereka tidak hanya formalitas belaka. Menurut Hotman Tohir Pohan (2008) Dewan komisaris independen adalah pihak yang tidak terafiliasi dalam segala hal dengan pemegang saham pengendali, tidak memiliki hubungan afiliasi dengan direksi atau dewan komisaris serta tidak menjabat sebagai direktur pada suatu perusahaan yang terkait dengan perusahaan pemilik. Dewan komisaris independen harus memahami undang-undang dan peraturan tentang pasar modal serta diusulkan oleh pemegang saham yang bukan merupakan pemegang saham pengendali dalam Rapat Umum Pemegang Saham (RUPS). Menurut Fenny Winata (2014) Dewan komisaris bertanggung jawab dan mempunyai kewenangan untuk mengawasi kebijakan dan kegiatan yang dilakukan direksi dan manajemen atas pengelolaan sumber daya perusahaan agar dapat berjalan secara efektif, efisien dan ekonomis dalam rangka mencapai tujuan organisasi, serta memberikan nasihat bilamana diperlukan. Karena posisinya yang sangat penting dalam perusahaan, kemampuan dan pemahaman komisaris terhadap bidang usaha dan emiten akan sangat mempengaruhi persetujuan dan keputusan yang dibuat, sehingga komisaris harus memiliki dan menguasai latar belakang pendidikan di bidang ekonomi.

Apabila jumlah komisaris independen pada dewan komisaris semakin banyak, maka akan semakin baik karena komisaris independen dapat memenuhi peran mereka didalam fungsi monitoring terhadap tindakan-tindakan para direktur, maka aktivitas tax avoidance akan semakin rendah. Berdasarkan pandangan Nurshamimi Sabli (2011), komisaris independen melakukan pengawasan yang sangat baik yaitu dengan mengarahkan perusahaan berdasarkan aturan yang telah ditetapkan. Hasil ini sejalan dengan penelitian Ayu Rahmawati (2016) menunjukkan bahwa dewan komisaris independen memiliki pengaruh yang signifikan terhadap penghindaran pajak (tax avoidance). Namun sebaliknya, penelitian ini berbanding terbalik dengan penelitian yang dilakukan oleh Nuralifmida Ayu Anissa (2011) menunjukkan bahwa dewan komisaris independen tidak memiliki pengaruh signifikan terhadap penghindaran pajak (tax avoidance). 


\section{KESIMPULAN DAN SARAN \\ Kesimpulan}

Hasil penelitian ini menunjukkan hasil yang konsisten dengan hipotesis pertama yang dibangun yaitu untuk menguji apakah kepemilikan institusional berpengaruh secara signifikan terhadap penghindaran pajak (tax avoidance) sehingga hipotesis pertama dan hipotesis kedua dalam penelitian ini diterima. Berdasarkan hasil dari analisis regresi berganda dengan tingkat signifikansi 5\% maka dapat disimpulkan kepemilikan institusional dan dewan komisaris independen berpengaruh signifikan terhadap penghindaran pajak (tax avoidance).

Saran

Berdasarkan hasil penelitian ini, maka diharapkan pada penelitian selanjutnya juga disarankan untuk memasukkan variabel lain yang mungkin mempengaruhi penghindaran pajak seperti kualitas audit, komite audit, kompensasi manajemen dan kepemilikan manajerial.

\section{DAFTAR PUSTAKA}

Ajzen, I. (1991) The Theory of Planned Behavior.Organizational Behavior and Human Decision Processes, 50: 179-211.

Ayu Rahmawati dkk .(2016). Pengaruh Pengungkapan Corporate Sosial Responsibility dan Corportae Governance Terhadap Tax Avoidance.Studi Pada Perusahaan Manufaktur yang Terdaftar Di BEI Tahun 2012-2014.Jurnal Perpajakan, Vol 10 N0.1 2016.

Chen, S., Chen X et.al. (2010). Are Family Firms more Tax Aggressive than Non Family Firms?. Journal of Financial Economics.

Elsiana Ruddian. (2017). PengaruhTata Kelola Perusahaan terhadap Penghindaran Pajak pada Perusahaan Pertambangan. Skripsi: Universitas Lampung.

Fenny Winata, (2014) . Pengaruh Corporate Governance Terhadap Tax Avoidance pada Perusahaan yang Terdaftar di Bursa Efek Indonesia Tahun 2013. TAX \& ACCOUNTING REVIEW, VOL. 4, NO.1, 2014.

Ghozali,Imam. 2013. Aplikasi Analisis Multivariate dengan Program IBM SPSS 21 Update PLS Regresi. Semarang: Badan Penerbit Universitas Diponegoro.

Hashemi Rodhian Hanum dan Zulaikha. (2013). Pengaruh Karakteristik Corporate Governance terhadap Effective Tax Rate. Diponegoro Journal of Accounting ISSN (Online): 2337-3806 Volume 2, Nomor 2, Tahun 2013 Halaman 1-10.

Hotman Tohir Pohan. (2008). Pengaruh Corporate Governace, Rasio Tobin Q, Perata Laba Terhadap Penghindaran Pajak Pada Perusahaan Publik. Jakarta: Universitas Trisakti.

Jensen, M. C., dan W. H. Meckling. (1976).Theory of the firm: Managerial behavior, agency costs and ownership structure." Journal of Financial Economics 3 (4): 305-360.

Maria Andriyani.( 2008). "Analisis Pengaruh Cash Ratio, Debt to Equity Ratio, Insider Ownership, Investment Opportunity Set, dan Profitability terhadap Kebijakan Dividen" Universitas Diponegoro, Semarang.

Nazaruddin dan Agus Tri Basuki.(2015). Analisis Statistik dengan SPSS.Yogyakarta: Danisa Media.

Ngadiman dan Puspitasari, C. (2014). "Pengaruh Leverage, Kepemilikan Institusional, dan Ukuran Perusahaan terhadap Penghindaran Pajak (Tax Avoidance). Jurnal Akuntansi,8(3), hal.408421.

Nuralifmida Ayu Annisa. (2011). Pengaruh Corporate Governance terhadap Tax Avoidance. Surakarta: Fakultas Ekonomi dan Bisnis, Universitas Sebelas Maret.

Nurshamimi Sabli. (2011). Tax Planning and Corporate Governance: Evidence from Shariah Compliant Companies. Universitas Teknologi MARA. 
Sartori,Nicola. (2010) .Effect of Strategic Tax Behaviors on Corporate Governance.www.ssrn.com Soerzawa, D., Yusmaniarti, Y., \& Suhendra, C. (2018). PENGARUH PENGHINDARAN PAJAK TERHADAP NILAI PERUSAHAAN DENGAN LEVERAGE SEBAGAI VARIABEL MODERASI. Bilancia : Jurnal Ilmiah Akuntansi,, 2(4), 367-377.

Tendi Haruman. (2008). Pengaruh Struktur Kepemilikan terhadap Keputusan Keuangan dan Nilai Perusahaan: Survey pada Perusahaan Manufaktur di Bursa Efek Indonesia. Simposium Nasional Akuntansi XI. 23-24 Juli 2008, Pontianak.. 2008. Pengaruh Struktur Kepemilikan terhadap Keputusan Keuangan dan Nilai Perusahaan: Survey pada Perusahaan Manufaktur di Bursa Efek Indonesia. Simposium Nasional Akuntansi XI. 23-24 Juli 2008, Pontianak

Tryana A.M. Tiraada, (2013), Kesadaran Perpajakan, Sanksi pajak, Sikap Fiskus Terhadap Kepatuhan WPOP Di Kabupaten Minahasa Selatan, Jurnal Fakultas Ekonomi dan Bisnis, Jurusan Akuntansi, Universitas Sam Ratulangi Manado.

Wien Ika Permanasari. (2010). Pengaruh Kepemilikan Manajerial, Kepemilikan Institusional, dan Corpotate Social Responsibility Terhadap Nilai Perusahaan. Jurnal Fakultas Ekonomi Universitas Diponegoro. 